\title{
Samtal III: Samtal om reflektion och dokumentation
}

Eva Borseman, Cecilia Hofsten, Mimmi Larsson, Elis Storesund, Ebba Theorell, Martin Wikmark

ES I dansen kan hända något nytt just när man börjar tycka det blir tråkigt: "Ska vi inte sluta någon gång?" Det är inte bara mysigt och kul att jobba med estetiska uttryck, utan både frustration och tålamod inkluderas.

EB Det där tycker jag stämmer med reflektionen och samtalet också att våga vänta $\mathrm{i}$ reflektionsrundor att det tar tid att komma underfund med vad som har hänt. Där kan jag som lärare känna att, jag har ju svaren! Att verkligen låta det få ta tid! Att ur tystnaden så kommer också nytt.

ET Vi pratade lite om det Elis och jag, det här med reflektionen och man kan bli rädd när det är tyst men hur ska man se på det här med att man alltid ska sätta ord på allt? Är det verkligen så nödvändigt? Är det verkligen så att orden är överordnade allt annat? Ibland kan det bli så att man sätter fel ord på någonting och då har man stöpt det $\mathrm{i}$ en form som inte alls blev ett bra slut. En reflektion kan stoppa ett flow i ett skapande. Den är inte alltid av godo. Men ibland måste man fånga upp det som hänt. Det kan ge upplevelsen en ytterligare dimension.

EB Det är verkligen sant!

$\mathrm{CH}$ Jag brukar citera Wittgenstein, ni vet det där kända citatet som avslutar Tractatus, att om det man inte kan tala, måste man tiga. Det tolkas ju ofta som att man ska vara tyst. Men kanske menade han istället att det som man inte kan sätta ord på måste man uttrycka på annat sätt.

Hur du refererar till det här kapitlet:

Borseman, E., Hofsten, C., Larsson, M., Storesund, E., Theorell, E. and Wikmark, M. 20I8. Samtal III: Samtal om reflektion och dokumentation. I: von Schantz, U., Thorgersen, K. and Lidén, A. (red.) De estetiska ämnenas didaktik Utmaningar, processer och protester. Pp. I63-I66. Stockholm: Stockholm University Press. DOI: https://doi.org/IO.I6993/bap.k. License: CC-BY 
ET Om vi tänker att vi kommer åt helt nya språkliga dimensioner, så är det kanske så att man måste låta upplevelsen eller insikten få verka ifred, över tid. Det blir väldigt snabbt ibland, snabbt inpå med reflektion och att beskriva vad man gjort. Då stöper man det igen i en ordform och den vanliga språkhierarkien är tillbaka.

ML: Den reflektionstid som ryms i en verkstadskurs är ju kanske inte den optimala. När det gäller vissa saker som man gör, så kanske det kan få gå år innan....

ML: Jag tänker på... det går ju rätt så snabbt i den här kursen till exempel. Nya intryck veckan efter och så där. Att det skulle vara fruktsamt med nån slags loggbok man samlar allting foton, filmer, reflektioner och att ... man tittar på det på nåt vis och Jag vet att dom hade nån sån--- nån examination eller redovisning förut --- men att då skulle dom visa det för sina gruppkompisar. Då hade de ju sett allting och gjort precis allting själv, men att det skulle vara av någon annan typ. Så att man kan gå tillbaks och tänka på "vad gjorde vi $i$ dansen första veckan ... att det..."

ES: Jag uppmanar dem att skriva, för att jag vet ju att i och med att det inte finns någon bild kvar och gå till så minns man inte. Studenterna får aldrig färdigt nedskrivet om vad vi har gjort, utan de får skriva ned och försöka minnas med kroppsminnet, och träna kroppsminnet. Vad vi har gjort för någonting? Det är jättesvårt att minnas. Hade de inte skrivit ned vad vi gjort och vad vi pratat om, så hade de inte haft med sig mycket från dansen. Text blir bärare av processer och uppgifter.

EB: Jag tycker också det.

ES: I början handlar reflektionen ju väldigt mycket om att våga gå utanför normen och att vara icke-konform. Om jag den första gången när vi gör dansleken "kom allihop" och jag t. ex. säger: ”Kom allihop, hoppandes!” Då har jag ofta tolv personer som hoppar exakt likadant. På en sekund så har alla uppfattat normen och gör likadant. Det är det vi börjar diskutera.

$\mathrm{CH}$ : Att dom hoppar samtidigt, menar du?

ES: De gör exakt samma rörelser. Händerna på samma sätt. De rör kropparna på samma sätt. Det finns ju sjuhundra sätt 
att hoppa. Men de hoppar exakt likadant. Det är fantastiskt, säger jag. Vilken enorm känsla ni har för att känna in i grupp. Men vad är tillåtet? Hur kan vi hoppa i det här rummet? För det är en utgångspunkt, från att börja våga experimentera, att gå utanför normen till vad det kan bli för någonting?

ET: En annan sak som vi pratade om - nu kanske jag inte ska gå förbi det här med reflektionen alltför snabbt, men det var ju det här med skratt, skratt, skratt. Alltså hur man ska förhålla sig till det. Det finns ju så många nyanser av skratt. Ibland är det ironiska skratt, ibland ursäktande, ibland är det bara det här lustfyllda... och ibland så bidrar det till en så otrolig koncentration och är utvecklande. Men ibland hindrar det en process, om det blir för mycket... och det stör kanske också dom andra. Jag vet inte hur brukar ni relatera till det här?

ES: Det som är mest hindrande, tycker jag är, när två till fyra personer i gruppen i danssituationer, etablerar kontakt med varandra i skratt, blickar och kommentarer. Det skapar avstånd till resten av gruppen och påverkar hela gruppen så otroligt mycket.

ET: Det är kanske liknande i drama. Det kanske är mindre så på bild och musik?

EB: Jag kan ju också se det där... det där skrattandet. Jag brukar... Brukar finns inte, för det beror ju på situation. Men ändå att tidigt låta dom prata två och två. Det använder jag mycket, för att alla ska få prata och att det inte blir långrandigt att höra alla och att det kan vara pinsamt att säga vad man tycker. Men att bara prata två och två. Hur tänker ni om olika sätt att skratta? Och då har man på nåt sätt....

ET: Ja du pratar om det så konkret?

EB: Ja ja!

$\mathrm{CH}$ : Eva! Gör du det då i stunden när det har uppkommit?

EB: Kanske inte exakt. Alltså det är ju också det här med... (kommentarer) Jag kan tänka hemma: "Oj! Sist så blev det så här. Hur ska jag göra nu?... Och just i stunden är det ju svårt. Men då kanske jag kan börja passet efter... Nån sån här reflektion två och två, brukar jag ha... efter första 
passet... när jag har tänkt på sånt som har stuckit ut lite... Och då blir det inte så dramatiskt och ingen blir utpekad. Och det kan vara så enkelt som sen ankomst också. Att prata två och två. Hur tänker ni kring det? Så att man inte: ”Nu är du sen igen!" Utan... Så har man en allmän... ett allmänt samtal om det.

$\mathrm{CH}$ : Grundkänslan är ju att det funkar. Det är roligt och det går bra. Men sen någon gång så är det en grupp som man får slita med. Och... nu minns jag inte om det var förra året eller kanske för två år sedan, men då var det i alla fall en grupp som jag hade klara svårigheter med. Jag kände inte att jag hade någon kontakt med dem. Att de inte hade några positiva förväntningar på mej. Så kändes det. Liksom. Det var så där viskande och pratande hela tiden. Och då blev jag ju arg alltså. Helt enkelt. Jag sa till några gånger och det hjälpte inte. Och då kände jag mig tvungen att vädja till dem som blivande förskollärare. Hur ser ni på den här situationen när det inte finns ett lyssnande oss emellan? Hur tänker ni själva, om ni skulle stå inför en barngrupp som ni inte får kontakt med? Jag förflyttade oss från vår lärandesituation till någon undervisningssituation som de antagligen kommer att möta längre fram.

EB: Hur gick det då?

$\mathrm{CH}$ : Ja, det kändes faktiskt som att det blev ett AHAAA! Ett slags uppvaknande. Men jag var ju ganska... Ja, jag var ju rätt bitchig, det får man lov att säga, men... jag tog till det då. 